p-ISSN: 1410-0029; e-ISSN2549-6786

Agrin Vol. 22, No. 1, April 2018

\title{
EFEKTIVITAS KNO3 TERHADAP PERTUMBUHAN DAN KANDUNGAN VITAMIN C KALE
}

\section{The Effectiveness of KNO3 Application on Growth and Vitamin C Content of Kale}

\author{
Heny Agustin* dan Annisa Nur Ichniarsyah \\ Program Studi Agroekoteknologi, Fakultas Bioindustri, Universitas Trilogi Jalan Taman \\ Makam Pahlawan, Kalibata No1, 12760, Jakarta \\ *Alamat Korespondesi: henyagustin@trilogi.ac.id
}

\begin{abstract}
ABSTRAK
Kandungan vitamin $\mathrm{C}$ yang tinggi pada kale membuat sayuran ini menjadi primadona. Berbagai upaya pada teknik budidaya dengan penambahan pupuk kalium dalam bentuk $\mathrm{KNO}_{3}$ dilakukan dengan harapan mampumeningkatkan pertumbuhan dan kandungan vitamin $\mathrm{C}$ nya. Penelitian ini bertujuan untuk mengetahui efektivitas $\mathrm{KNO}_{3}$ pada berbagai konsentrasi terhadap pertumbuhan dan kandungan vitamin $\mathrm{C}$ pada kale. Penelitian dilaksanakan dari Januari hingga Oktober 2017 dengan menggunakan dua jenis kale yaitu Nero Toscana (kultivar daun hijau) dan Curly Scarlet (kultivar daun ungu) tanpa dimaksudkan untuk membandingkan keduanya. Penelitian menggunakan Rancangan Acak Kelompok (RAK) satu faktor yaitu konsentrasi $\mathrm{KNO}_{3}$ yang terdiri atas 5 taraf: tanpa $\mathrm{KNO}_{3}$ (kontrol), $2 \mathrm{~g} / \mathrm{L}, 4 \mathrm{~g} / \mathrm{L}, 6 \mathrm{~g} / \mathrm{L}, 8 \mathrm{~g} / \mathrm{L}$. Karakter pertumbuhan, hasil panen dan kandungan vitamin $\mathrm{C}$ diamati pada penelitian ini. Hasil percobaan menunjukkan bahwa pemberian $\mathrm{KNO}_{3}$ secara umum tidak memberikan dampak nyata terhadap pertumbuhan dan hasil panen kale hijau. Namun aplikasi $\mathrm{KNO}_{3}$ dengan konsentrasi $8 \mathrm{~g} / \mathrm{L}$ berhasil meningkatkan kandungan vitamin C dibandingkan seluruh perlakuan dengan rata-rata $120.29 \mathrm{mg} / 100 \mathrm{~g}$ dari lima kali panen. Puncak vitamin C sebesar $152.18 \mathrm{mg} / 100 \mathrm{~g}$ terjadi saat kale hijau dipanen pada usia 175 hari setelah tanam (HST). Sementara pada kale ungu pemupukan $\mathrm{KNO}_{3}$ dengan konsentrasi $8 \mathrm{~g} / \mathrm{L}$ mampu meningkatkan tinggi tanaman lebih besar $6.18 \mathrm{~cm}$ dan luas daun lebih besar $14.19 \mathrm{~cm}^{2}$ dibandingkan kontrol tetapi tetap tidak berdampak pada hasil panennya. Kandungan vitamin $\mathrm{C}$ pada kale ungu berhasil ditingkatkan dengan perlakuan $\mathrm{KNO}_{3} 8 \mathrm{~g} / \mathrm{L}$ dengan rata-rata $141.13 \mathrm{mg} / 100 \mathrm{~g}$ dari lima kali panen. Puncak vitamin $\mathrm{C}$ sebesar $182.3 \mathrm{mg} / 100 \mathrm{~g}$ terjadi saat kale ungu dipanen pada usia 85 HST.
\end{abstract}

Kata kunci:kale Nero Toscana, kale Curly Scarlet, pupuk kalium, waktu panen

\section{ABSTRACT}

Kale contains high vitamin $C$ and makes it become a vegetables that are in great demand. One of various efforts on cultivation techniques such as the application of potassium fertilizer was done to improve growth and increase vitamin C content. This research aimed to observe the effectiveness of $\mathrm{KNO}_{3}$ in various concentrations on growth and vitamin C content. The research was done from January-July 2017, using two varieties of kale; Nero Toscana (green-leaf cultivar) and Curly Scarlet (purple-leaf cultivar) without intending to compare both varieties. Research design used was 1-factor randomized group design ( $\mathrm{KNO}_{3}$ concentration) consists of 5 levels: without $\mathrm{KNO}_{3}$ (control), $2 \mathrm{~g} / \mathrm{L}, 4 \mathrm{~g} / \mathrm{L}, 6 \mathrm{~g} / \mathrm{L}$, and $8 \mathrm{~g} / \mathrm{L}$. Characteristics of growth, yields and vitamin $\mathrm{C}$ content were observed in this study. From the results, it can be seen that the application of $\mathrm{KNO}_{3}$ generally did not give significant effect on growth and yield. However, the application of $8 \mathrm{~g} / \mathrm{L} \mathrm{KNO}_{3}$ concentration successfully increased the vitamin C content compared to other treatments with average of $120.29 \mathrm{mg} / 100 \mathrm{~g}$ of five harvests. The highest vitamin C content was $152.18 \mathrm{mg} / 100 \mathrm{~g}$ obtained at 175 days after planting. The application of $\mathrm{KNO}_{3}$ on purple kale at $8 \mathrm{~g} / \mathrm{L} \mathrm{KNO}$ concentration was able to increase its height about $6.18 \mathrm{~cm}$ and leaf area meter at $14.19 \mathrm{~cm}^{2}$ compared to control. However, the application did not give significant effect on its yield. The vitamin $C$ content of purple kale could be increased with $\mathrm{KNO}_{3}$ application at $8 \mathrm{~g} / \mathrm{L}$ with average of $141.13 \mathrm{mg} / 100 \mathrm{~g}$ of five harvests. The highest vitamin C content (182.63 mg/100 g) obtained at 85 Days After Planting.

Key words: Nero Toscana, Curly Scarlet, potassium fertilizer, growth and yield

\section{PENDAHULUAN}

Tanaman kale saat ini sedang menjadi primadona komoditi hortikultura yang banyak diminati masyarakat. Kale adalah jenis sayuran dengan daun berwarna hijau atau ungu kebiruan (bergantung pada 
kultivar) yang daun sejatinya tidak membentuk kepala seperti layaknya kubis, brokoli atau kembang kol, collard, brussels sprout, kohlrabi, atau sayuran-sayuran jenis keluarga kubis (Brassicaoleracea) pada umumnya. Kelebihan kale terletak pada kandungan vitamin $\mathrm{C}$ nya yang tinggi hingga mencapai 109.43 mg/100 g (Acikgoz 2011). Kale juga diketahui mengandung zat anti kanker (sulphoraphane) yang muncul ketika sayuran dipotong (Korus, 2011). Kandungan karbohidrat kale dianggap sebagai makanan kesehatan yang mengenyangkan karena diperkaya olehprebiotik dan serat makanan yang berpotensi mengurangi risiko penyakit seperti obesitas, kanker, jantung, dan diabetes (Migliozzi et al., 2015).

Berbagai kelebihan kale membuat permintaan akan sayuran ini meningkat, sehingga perlu upaya untuk meningkatkan produksi dan kualitasnya dengan perlakuan pemupukan khususnya pemberian kalium dalam bentuk $\mathrm{KNO}_{3}$. Pemberian $\mathrm{KNO}_{3}$ sebesar $4 \mathrm{~g} / \mathrm{L}$ dilaporkan berpengaruh nyata terhadap umur panen kailan, berat segar per tanaman dan berat tanaman yang layak dikonsumsi (Zuhry, 2010). Aplikasi $\mathrm{KNO}_{3}$ pada kailan sebesar $250 \mathrm{~kg} / \mathrm{ha}$ melalui pemupukan di tanah mampu meningkatkan tingkat kehijauan daun hingga 6,10\% dan indeks luas daun sebesar 18,57\% (Ramadiana, 2011). Pemberian KNO3 juga dilaporkan mampu meningkatkan panjang petiol hingga $74.91 \mathrm{~cm}$ pada tanaman ilesiles (Khalimah, 2011), mampu meningkatkan berat buah per petak dan panjang buah mentimun sampai panen umur 49 HST (Purnomo, 2013), meningkatkan bobot kering daun pada tembakau sebesar 52.33 g (Hutapea dkk., 2014) serta mampu meningkatkan tinggi tanaman bawang merah pada usia 5-7 MST (Koheri dkk., 2015).

Pemberian pupuk kalium dalam bentuk $\mathrm{KNO}_{3}$ diharapkan dapat meningkatkan kuantitas yang tercermin pada hasil panen dan kualitas khususnya kandungan vitamin $\mathrm{C}$ pada kale.Penelitian ini bertujuan untuk mengetahui efektivitas aplikasi $\mathrm{KNO}_{3}$ pada berbagai konsentrasi terhadap pertumbuhan dan kandungan vitamin $\mathrm{C}$ kale.

\section{METODE}

Penelitian ini dilaksanakan pada bulan Januari hingga Oktober 2017.Penyemaian dan penanaman kale dilakukan di Kebun Percobaan Agroekoteknologi dan pengujian kandungan vitamin $\mathrm{C}$ dilakukan di Laboratorium Terpadu Agroekoteknologi, Universitas Trilogi, Jakarta. Bahan yang digunakan adalah benih kale kultivar berdaun hijau Nero Toscana dan berdaun ungu Curly Scarlet, KNO3, iodine, KI, amilum, kompos, sekam bakar, kertas 
saring, label, plastik, aquades dan ATK. Alat yang digunakan antara lain: erlenmayer, pipet mohr $5 \mathrm{ml}$, pipet mohr 10 $\mathrm{ml}$, labu ukur $100 \mathrm{ml}$, buret, statif, klem, spatula, mortar berdiameter $16 \mathrm{~cm}$, corong, timbangan analitik $0,01 \mathrm{~g}$ dan $0,1 \mathrm{~g}$, polibag ukuran $40 \mathrm{~cm} \times 40 \mathrm{~cm}$, tray 50 lubang, sprayer, jangka sorong digital danmeteran.Percobaan ini menggunakan metode Rancangan Acak Kelompok (RAK) satu faktor yaitukonsentrasi $\mathrm{KNO} 3$ yang terdiri atas 5 taraf: tanpa KNO3 (kontrol), 2 g/L, 4 g/L, 6 g/L serta 8 g/L. Percobaan ini dilakukan pada dua jenis kultivar kale yang tidak dimaksudkan untuk membandingkan keduanya. Setiap perlakuan akan diulang sebanyak empat kali sehingga diperoleh 20 unit percobaan per kultivar. Setiap unit percobaan terdiri atas 10 tanaman contoh sehingga terdapat 200 satuan tanaman percobaan setiapkultivarnya. Analisis ragam akan dilakukan untuk mengetahui pengaruh perlakuan terhadap tolok ukur yang diamati. Apabila dalam analisis ragam terdapat perbedaan nyata pada taraf $\alpha=5 \%$ maka dilakukan uji nilai tengah dengan prosedur Duncan (Gomez and Gomez, 1995).

Penyemaian kale melalui benih dilakukan dalam net house dengan menggunakan tray 50 lubang yang berisi campuran media tanam kompos dan sekam bakar. Kale yang telah tumbuh dengan usia 10 hari setelah tanam (HST) atau telah memiliki 3-4 daun sejati kemudian dipindah tanam ke dalam polibag dengan ukuran $40 \mathrm{~cm}$ x $40 \mathrm{~cm}$. Pemupukan $\mathrm{KNO}_{3}$ dilakukan satu minggu setelah pindah tanam dan dilakukan dengan interval seminggu sekali secara berkala hingga pemanenan kelima atau pada usia 175 hari setelah tanam (HST). Pemupukan dilakukan dengan menggunakan hand sprayer yang disemprotkan ke seluruh bagian tubuh tumbuhan dengan beberapa konsentrasi yang telah ditentukan. Pemeliharaan tanaman meliputi penyiraman, penyiangan gulma, dan pengendalian hama penyakit.

Pemanenan dilakukan dengan memotong bagian daun (tanpa mencabut tanaman) dan menyisakan 5 daun termuda dibagian atas untuk kale hijau serta 3 daun termuda dibagian atas untuk kale ungu. Pemanenan pertama dilakukan pada usia 55 HST dan selanjutnya setiap 30 hari setelahnya dilakukan pemanenan tahap kedua hinggakelima. Pengamatan respon pertumbuhan tanaman dilakukan setiap kali panen, diantaranya: tinggi tanaman $(\mathrm{cm})$ dilakukan dengan mengukur tinggi tanaman dari batang diatas permukaan tanah sampai ujung tanaman dengan menggunakan penggaris/meteran; diameter batang $(\mathrm{cm})$ dilakukan dengan mengukur diameter pada bagian pangkal, tengah maupun pucuk batang dengan menggunakan jangka sorong digital; jumlah daun (helai) dilakukan dengan menghitung jumlah daun yang 
tumbuh setiap kali panen; luas daun $\left(\mathrm{cm}^{2}\right)$ dilakukan dengan menghitung panjang dan lebar daun yang dipanen dengan metode millimeter blok, bobot daun layak konsumsi (gram) dilakukan dengan memilah daun yang telah dipanen dengan standar layak konsumsi (daun kale segar, utuh, tidak terkena hama maupun penyakit).

Analisis kandungan vitamin $\mathrm{C}$ dilakukan dengan metode titrasi iodometri.Daun kale yang telah dipanen kemudian ditimbang sebanyak 10 gram dan dihaluskan dengan menggunakan mortar.Daun kale yang sudah dihaluskan kemudian dimasukkan ke dalam labu ukur dan ditambahkan akuades ke dalamnya sampai mencapai batas tera $100 \mathrm{~mL}$ kemudian disaring. Hasil saringan (filtrat) diambil sebanyak $25 \mathrm{~mL}$ dan dimasukkan ke dalam tiga gelas erlenmeyer yang kemudian ditambahkan 3 tetes larutan amilum ke masing-masing erlenmayer. Filtrat kale yang telah diberikan amilum kemudian dititrasi dengan larutan iodin standar $0,01 \mathrm{~N}$ yang dibuat dari bahan $\mathrm{KI}$ dan iodine sampai larutan berwarna biru. Kandungan vitamin $\mathrm{C}$ dihitung dengan rumus sebagai berikut:

Vit. C (mg/100 g) = Vi. Fp. 0,88.100 mg Keterangan:

Vit. $\mathrm{C}=$ Vitamin $\mathrm{C}$

$\mathrm{Vi} \quad=$ volume iodine

$\mathrm{fp} \quad=$ faktor pengencer

$\mathrm{mg}=$ berat sampel

\section{HASIL DAN PEMBAHASAN}

\section{Pengaruh aplikasi KNO3 terhadap pertumbuhan dan hasil kale hijau}

Pemberian pupuk $\mathrm{KNO}_{3}$ secara umum tidak memberikan dampak terhadap pertumbuhan dan hasil panen kale hijau (Tabel 1). Pemberian pupuk $\mathrm{KNO}_{3}$ dengan konsentrasi 6 g/L sebetulnya mampu memberikan pengaruh terhadap tinggi tanaman sebesar 5,21 cm dibandingkan dengan kontrol (Tabel 1). Namun respon tersebut sayangnya tidak diikuti oleh peubah lainnya, termasuk hasil panen yang ditunjukkan pada peubah bobot daun layak konsumsi yang menghasilkan besaran yang sama dengan kontrol (Tabel 1).

Tabel 1. Pengaruh perlakuan konsentrasi $\mathrm{KNO}_{3}$ terhadap pertumbuhan kale hijau

\begin{tabular}{lllllc}
\hline Perlakuan & \multicolumn{5}{c}{ Rerata lima kali panen } \\
\cline { 2 - 6 } & $\begin{array}{c}\text { Tinggi } \\
\text { tanaman } \\
(\mathrm{cm})\end{array}$ & $\begin{array}{c}\text { Jumlah } \\
\text { daun } \\
\text { (helai) }\end{array}$ & $\begin{array}{c}\text { Lebar } \\
\text { daun } \\
\left(\mathrm{cm}^{2}\right)\end{array}$ & $\begin{array}{c}\text { Diameter } \\
\text { batang } \\
(\mathrm{cm})\end{array}$ & $\begin{array}{c}\text { Bobot daun } \\
\text { layak konsumsi } \\
(\mathrm{g})\end{array}$ \\
\hline Kontrol & $33,74 \mathrm{~b}$ & $23,80 \mathrm{ab}$ & $78,23 \mathrm{a}$ & $10,01 \mathrm{a}$ & $49,16 \mathrm{a}$ \\
$\mathrm{KNO}_{3} 2 \mathrm{~g} / \mathrm{L}$ & $31,82 \mathrm{bc}$ & $21,87 \mathrm{~b}$ & $66,68 \mathrm{a}$ & $9,21 \mathrm{~b}$ & $41,07 \mathrm{a}$ \\
$\mathrm{KNO}_{3} 4 \mathrm{~g} / \mathrm{L}$ & $29,29 \mathrm{c}$ & $24,68 \mathrm{a}$ & $66,31 \mathrm{a}$ & $9,18 \mathrm{~b}$ & $39,77 \mathrm{a}$ \\
$\mathrm{KNO}_{3} 6 \mathrm{~g} / \mathrm{L}$ & $38,95 \mathrm{a}$ & $23,39 \mathrm{ab}$ & $66,20 \mathrm{a}$ & $8,95 \mathrm{~b}$ & $38,81 \mathrm{a}$ \\
$\mathrm{KNO}_{3} 8 \mathrm{~g} / \mathrm{L}$ & $32,00 \mathrm{bc}$ & $22,24 \mathrm{~b}$ & $77,36 \mathrm{a}$ & $10,02 \mathrm{a}$ & $45,95 \mathrm{a}$ \\
\hline
\end{tabular}

Keterangan: Angka yang diikuti oleh huruf yang sama dalam satu kolom tidak berbeda nyata dengan DMRT pada $\alpha=5 \%$ 


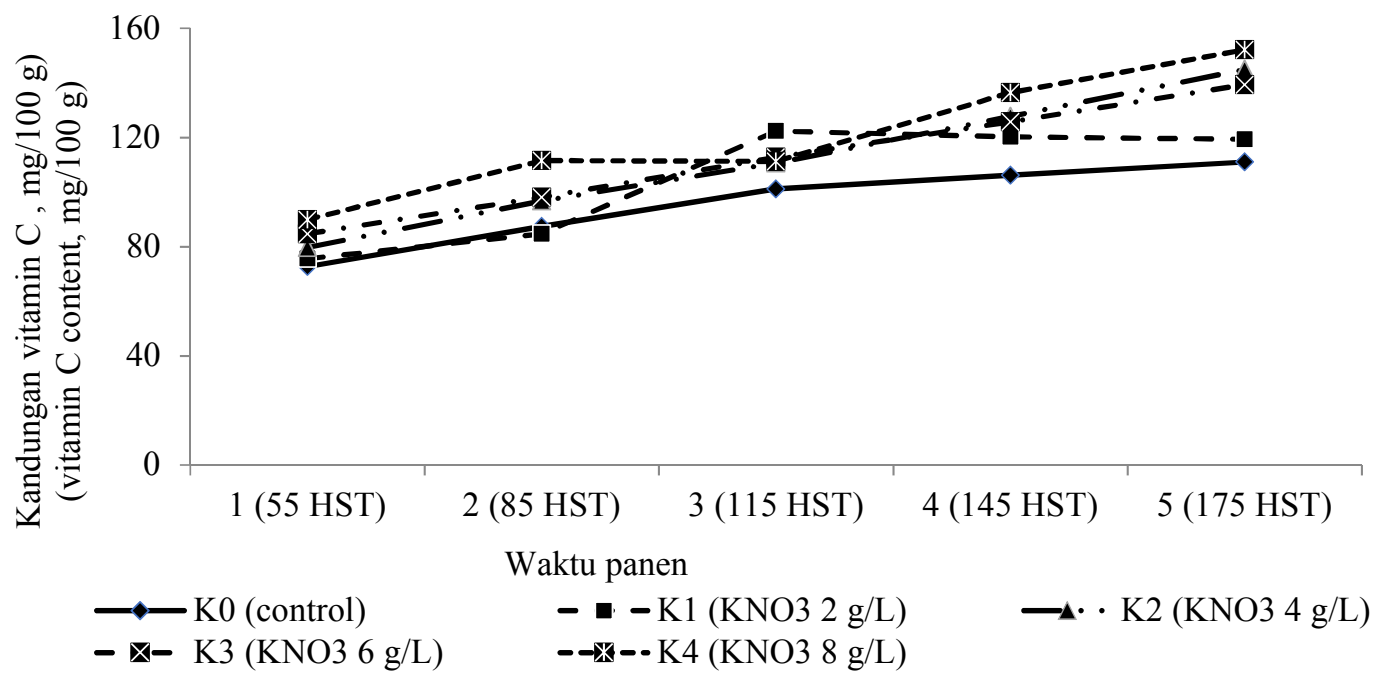

Gambar 1. Kandungan vitamin $\mathrm{C}$ kale hijau dengan berbagai perlakuan $\mathrm{KNO}_{3}$ di beberapa waktu panen.

Pemberikan pupuk $\mathrm{KNO}_{3}$ dengan konsentrasi $2 \mathrm{~g} / \mathrm{L}-8 \mathrm{~g} / \mathrm{L}$ diduga belum mampu meningkatkan produksi kale hijau dalam lima kali pemanenan yang dilakukan. Tidak adanya respon peningkatan produksi tanaman pada kale hijau dapat disebabakan oleh beberapa faktor seperti konsentrasi $\mathrm{KNO}_{3}$ yang belum optimal, tidak efisiennya pemberikan $\mathrm{KNO}_{3}$ dengan interval satu minggu sekali atau kurang efektifnya pemberian $\mathrm{KNO}_{3}$ dengan cara penyemprotan melalui daun. Menurut Khalimah (2011) pengaplikasian $\mathrm{KNO}_{3}$ dengan cara disiram memberikan hasil terbaik terhadap komponen vegetatif tanaman iles-iles karena tidak menimbulkan kerusakan pada daun, selain itu juga pupuk yang diberikan di sekitar akar langsung diserap oleh tanaman dan minimnya hara yang hilang melalui prosespencucian.

Perlakuan pemberian $\mathrm{KNO}_{3}$ dengan cara penyemprotan ke daun sebetulnya mengarah pada sistem kerja kalium yang berperan dalam membuka dan menutupnya stomata (jika daun mempunyai kandungan air yang cukup dan suhunya tidak ekstrim). Mekanisme kerja kalium dalam membuka dan menutup stomata ini dipengaruhi oleh cahaya yang ketika daun terpapar cahaya maka terjadi peningkatan dosis $\mathrm{K}$ yang akan menstimulasi osmosis air dari sel epidermis ke dalam sel penjaga yang cukup untuk meningkatkan tekanan turgor yang diperlukan dalam pembukaan stomata. Hal ini akan memudahkan $\mathrm{CO}_{2}$ berdifusi secara cepat ke dalam daun. Akibatnya, laju fotosintesis meningkat dan banyak karbohidrat yang tersedia untuk perkembangan dan pertumbuhan tanaman (Salisbury and Ross 1995). Pemberian $\mathrm{KNO}_{3}$ diharapkan mampu meningkatkan pertumbuhan tanaman yang ditunjukkan dengan bobot daun tinggi sehingga layak dikonsumsi. 
Tidak adanya respon terhadap pertumbuhan kale hijau setelah pemberian $\mathrm{KNO}_{3}$ tidak serta merta membuat kualitas panen kale hijau berakhir pada hasil yang sama. Pemberian $\mathrm{KNO}_{3}$ pada kale hijau nyatanya mampu meningkatkan kualitas panennya yang ditunjukkan pada kandungan vitamin $\mathrm{C}$ yang dihasilkan (Gambar 1). Kandungan vitamin $\mathrm{C}$ pada kale hijau meningkat seiring dengan waktu panen (Gambar 1).

Pada beberapa perlakuan di waktu panen yang berbeda, kandungan vitamin $\mathrm{C}$ sempat mengalami penurunan kemudian meningkat kembali (Gambar 1).Secara umum dapat terlihat bahwa kandungan vitamin $\mathrm{C}$ kale hijau yang dipanen pada tahap kelima meningkat dibandingkan saat panen pertama. Hal ini senada dengan penelitian Acikgoz (2011) yang menyatakan bahwa kandungan vitamin $\mathrm{C}$ pada kale meningkat seiring umur tanamannya. Kale yang dipanen pada tahap ketiga atau saat berbunga diusia 22 minggu setelah transplanting (MST) mengandung vitamin C lebih tinggi yaitu sebesar 109,43 $\mathrm{mg} / 100 \mathrm{~g}$ dibandingkan yang dipanen pada tahap kedua (21 MST)sebesar 105,21 $\mathrm{mg} / 100 \mathrm{~g}$, dan tahap pertama saat fase roset atau $18 \mathrm{MST}$ sebesar 98,30 $\mathrm{mg} / 100 \mathrm{~g}$. Meskipun pemanenan kale hijau pada tahap kelima masih dalam fase vegetatif namun kandungan vitamin $\mathrm{C}$ tetap meningkat seiring dengan kematangan daun dan usia tanaman.

Kandungan vitamin $\mathrm{C}$ tinggi terjadi pada panen kelima atau umur tanaman 175 HST pada seluruh perlakuan yang diberikan. Kandungan vitamin $\mathrm{C}$ yang dihasilkan oleh kale hijau tercatat paling tinggi sebesar 152,18 mg/100 g dengan

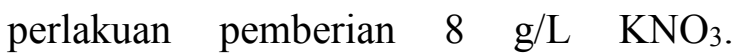
Berdasarkan rataan kandungan vitamin $\mathrm{C}$ yang dihasilkan oleh kale hijau, perlakuan $\mathrm{KNO}_{3}$ dengan konsentrasi $8 \quad \mathrm{~g} / \mathrm{L}$ memberikan dampak terbaik dengan jumlah rata-rata $120,29 \mathrm{mg} / 100 \mathrm{~g}$ dibandingkan seluruh perlakuan yang diberikan. Perbedaan hasil antara kualitas dan kuantitas kale hijau dengan perlakuan pemberian $\mathrm{KNO}_{3}$ konsentrasi $8 \mathrm{~g} / \mathrm{L}$ mampu meningkatkan kandungan vitamin $\mathrm{C}$ yang dihasilkan.

\section{Pengaruh aplikasi $\mathrm{KNO}_{3}$ terhadap pertumbuhan dan hasil kale ungu}

Perlakuan pemberian $\mathrm{KNO}_{3}$ sebagai pupuk tambahan nyatanya hanya berdampak pada peubah tinggi tanaman dan luas daun kale ungu (Tabel 2). Pemberian aplikasi $\mathrm{KNO}_{3}$ dengan konsentrasi $8 \mathrm{~g} / \mathrm{L}$ mampu meningkatkan $6,18 \mathrm{~cm}$ tinggi tanaman dan $14.19 \mathrm{~cm}^{2}$ luas daun kale ungu dibandingkan kontrol (Tabel 2).

Tidak adanya respons terhadap pertumbuhan kale ungu yang juga dialami oleh kale hijau, makin menguatkan dugaan bahwa penambahan $\mathrm{KNO}_{3}$ dengan cara penyemprotan dinilai tidak cukup efektif 
diberikan. Meskipun demikian pemberian $\mathrm{KNO}_{3}$ tetap mampu meningkatkan peubah tinggi tanaman yang menghasilkan perbedaan dibandingkan kontrol. Hal ini pernah diungkapkan oleh Koheri dkk. (2015) yang menyatakan bahwa pemberian $\mathrm{KNO}_{3}$ pada tanaman bawang merah dengan waktu peangaplikasian dan konsentrasi pupuk yang lebih banyak berpengaruh pada tinggi tanaman karena unsur kalium berperan penting dalam pertumbuhan dan pembentukan karbohidrat untuk pertumbuhan. Namun peubah tinggi tanaman tidak cukup mampu meningkatkan hasil panen kale ungu dibandingkankontrol.

Kandungan vitamin $\mathrm{C}$ yang dihasilkan oleh kale ungu dengan pemberian $\mathrm{KNO}_{3}$ pada beberapa konsentrasi mengalami fluktuasi (Gambar 2).Kandungan vitamin $\mathrm{C}$ pada kale ungu mulai meningkat tajam saat panen kedua diusia 85 HST yang kemudian terus menurun hingga waktu panen kelima (Gambar 2). Meskipun demikian, secara keseluruhan kandungan vitamin $\mathrm{C}$ pada kale ungu mengalami peningkatkan dibandingkan saat panen pertama kali.

Tabel 2. Pengaruh perlakuan konsentrasi $\mathrm{KNO}_{3}$ terhadap pertumbuhan kale ungu

\begin{tabular}{llcccc}
\hline \multirow{2}{*}{ Perlakuan } & \multicolumn{5}{c}{ Rerata lima kali panen } \\
\cline { 2 - 6 } & $\begin{array}{c}\text { Tinggi } \\
\text { tanaman } \\
(\mathrm{cm})\end{array}$ & $\begin{array}{c}\text { Jumlah } \\
\text { daun } \\
(\text { helai })\end{array}$ & $\begin{array}{c}\text { Lebar } \\
\text { daun } \\
(\mathrm{cm} 2)\end{array}$ & $\begin{array}{c}\text { Diameter } \\
\text { batang } \\
(\mathrm{cm})\end{array}$ & $\begin{array}{c}\text { Bobot daun } \\
\text { layak konsumsi } \\
(\mathrm{g})\end{array}$ \\
\hline Kontrol & $33,04 \mathrm{c}$ & $10,74 \mathrm{a}$ & $87,62 \mathrm{~b}$ & $9,29 \mathrm{a}$ & $28,34 \mathrm{a}$ \\
$\mathrm{KNO}_{3} 2 \mathrm{~g} / \mathrm{L}$ & $35,94 \mathrm{abc}$ & $10,66 \mathrm{a}$ & $96,33 \mathrm{ab}$ & $9,68 \mathrm{a}$ & $32,61 \mathrm{a}$ \\
$\mathrm{KNO}_{3} 4 \mathrm{~g} / \mathrm{L}$ & $34,67 \mathrm{bc}$ & $10,66 \mathrm{a}$ & $92,04 \mathrm{ab}$ & $9,01 \mathrm{a}$ & $30,65 \mathrm{a}$ \\
$\mathrm{KNO}_{3} 6 \mathrm{~g} / \mathrm{L}$ & $36,68 \mathrm{ab}$ & $11,50 \mathrm{a}$ & $93,64 \mathrm{ab}$ & $9,49 \mathrm{a}$ & $32,37 \mathrm{a}$ \\
$\mathrm{KNO}_{3} 8 \mathrm{~g} / \mathrm{L}$ & $39,22 \mathrm{a}$ & $10,70 \mathrm{a}$ & $101,81 \mathrm{a}$ & $9,47 \mathrm{a}$ & $36,16 \mathrm{a}$ \\
\hline
\end{tabular}

Keterangan: Angka yang diikuti oleh huruf yang sama dalam satu kolom tidak berbeda nyata denganDMRT pada $\alpha=5 \%$.
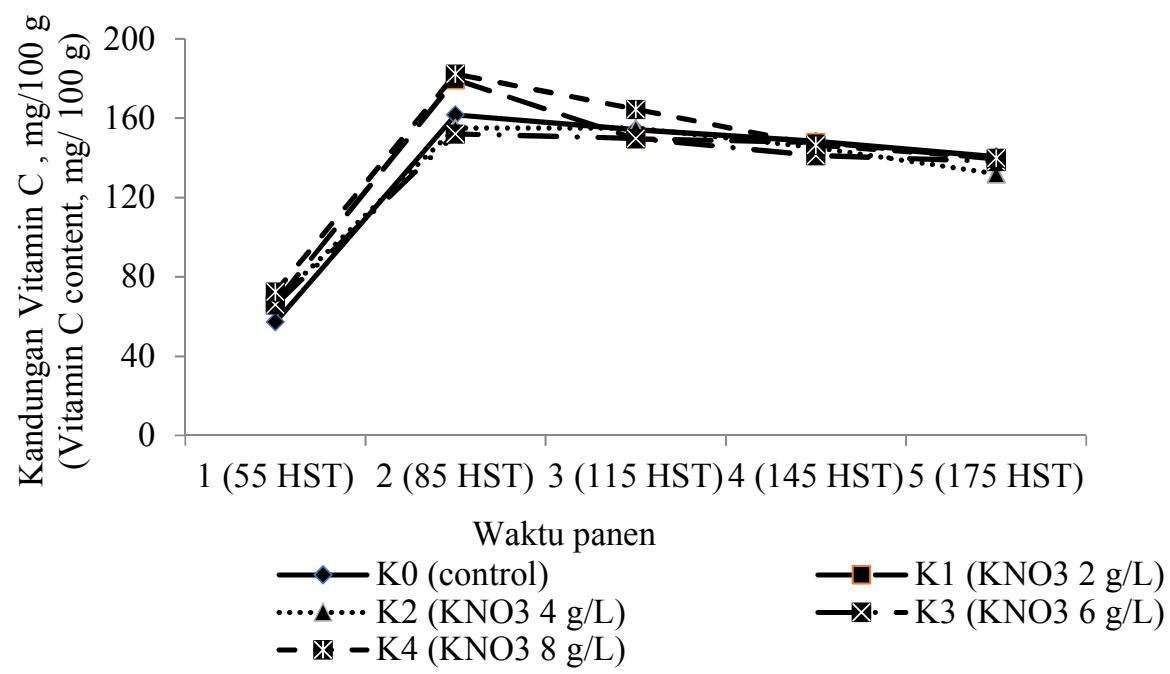

Gambar 2. Kandungan vitamin $\mathrm{C}$ kale ungu dengan berbagai perlakuan $\mathrm{KNO}_{3}$ di beberapa waktu panen. 
Kadar vitamin $\mathrm{C}$ tinggi pada kale ungu terjadi saat waktu panen kedua atau memasuki usia 85 hari setelah tanam (HST). Pada usia tanam tersebut seluruh perlakuan menunjukkan hasil kandungan vitamin $\mathrm{C}$ tertinggi. Dari seluruh perlakuan, pemberian $\mathrm{KNO}_{3} 8 \mathrm{~g} / \mathrm{L}$ memberikan hasil terbaik dengan jumlah vitamin $\mathrm{C}$ sebesar $182.3 \mathrm{mg} / 100$ g. Kandungan ini sangat tinggi dibandingkan kontrol yang hanya menghasilkan $161.66 \mathrm{mg} / 100 \mathrm{~g}$ vitamin $\mathrm{C}$. Meskipun sempat menurun pada waktu panen setelahnya, namun rata-rata kandungan vitamin $\mathrm{C}$ yang diperoleh dari perlakuan $\quad \mathrm{KNO}_{3} \quad 8 \quad \mathrm{~g} / \mathrm{L} \quad$ mampu menghasilkan kandungan vitamin $\mathrm{C}$ sebesar $141.13 \mathrm{mg} / 100 \mathrm{~g}$ lebih tinggi dibandingkan seluruh perlakuan yang diberikan. Jumlah kandungan vitamin $\mathrm{C}$ kale ungu yang ditanam di lingkungan tropis dinilai cukup tinggi meskipun tidak ditanam pada habitat aslinya. Berdasarkan data, rata-rata kandungan vitamin $\mathrm{C}$ kale yang ditanam di lingkungan subtropis menghasilkan: 102 mg/100 g (Korus, 2011), 109,43 mg/100 g (Acikgoz, 2011) dan 52,25 - 77,91 mg/100 g (Sikora and Bodziar, 2012). Salah satu faktor yang mampu mempengaruhi kadar vitamin $\mathrm{C}$ adalah lamanya intensitas cahaya matahari (Ligor and Buszewski, 2012).

Menurut Mozafar (2008), pupuk nitrogen dosis tinggi cenderung menyebabkan penurunan kandungan vitamin $\mathrm{C}$ pada banyak buah dan sayuran.
Mozafar (2008) menambahkan bahwa pupuk yang mengandung nitrogen dalam jumlah yang tinggi dapat menurunkan konsentrasi vitamin $\mathrm{C}$ pada berbagai buah dan sayuran, misalnya kentang, tomat, dan jeruk. Namun pemberian $\mathrm{KNO}_{3} 8 \mathrm{~g} / \mathrm{L}$ pada kale ungu berdampak sebaliknya, hal ini menunjukkan bahwa konsentrasi nitrogen pada $\mathrm{KNO}_{3} 8 \mathrm{~g} / \mathrm{L}$ dalam jumlah yang tepat dan efektif untuk diberikan.

\section{KESIMPULAN}

1. Aplikasi pemupukan $\mathrm{KNO}_{3}$ pada kosentrasi berbeda belum mampu meningkatkan kuantitas hasil panen pada kale hijau dan kale ungu yang diuji.

2. Aplikasi $\mathrm{KNO}_{3}$ pada konsentrasi $8 \mathrm{~g} / \mathrm{L}$ mampu meningkatkan kualitas kale khususnya kandungan vitamin $\mathrm{C}$ kale hijau yang lebih tinggi dibandingkan kontrol. Rata-rata kandungan vitamin $\mathrm{C}$ pada kale hijau dengan pemberian KNO3 $\quad 8$ g/L menghasilkan 120.29 $\mathrm{mg} / 100 \mathrm{~g}$ dari lima kali panen yang dilakukan dengan puncak vitamin $\mathrm{C}$ sebesar $152.18 \mathrm{mg} / 100 \mathrm{~g}$ yang terjadi saat kale hijau dipanen pada usia 175 hari setelah tanam (HST).

3. Aplikasi $\mathrm{KNO}_{3}$ pada konsentrasi $8 \mathrm{~g} / \mathrm{L}$ mampu meningkatkan kualitas kale khususnya kandungan vitamin C nya kale ungu lebih tinggi dibandingkan kontrol. Rata-rata kandungan vitamin $\mathrm{C}$ 
pada kale ungu dengan pemberian

KNO3 8 g/L menghasilkan 141.13 $\mathrm{mg} / 100 \mathrm{~g}$ dari lima kali panen yang dilakukan dengan puncak vitamin $\mathrm{C}$ sebesar $182.3 \mathrm{mg} / 100 \mathrm{~g}$ yang terjadi saat kale hijau dipanen pada usia 85 HST.

\section{UCAPAN TERIMAKASIH}

Penulis mengucapkan terimakasih kepada Kementrian Riset Teknologi dan Pendidikan Tinggi atas hibah yang diterima pada skim Penelitian Dosen Pemula tahun 2017.

\section{DAFTAR PUSTAKA}

Acikgoz, F. E. 2011. Mineral, vitamin C and crude protein contents in kale (Brassica oleraceae var. acephala) at different harvesting stages. African Journal of Biotechnology, 10(75): 17170 - 17174.

Gomez, K. A. dan A. A. Gomez. 1995. Prosedur statistik untuk penelitian pertanian. Diterjemahkan oleh E. Syamsuddin dan S. B. Justika. Universitas Indonesia Press, Jakarta.

Hutapea, A. S., T. Hadiastono, and M. Martosudiro. 2014. Pengaruh pemberian pupuk kalium $\left(\mathrm{KNO}_{3}\right)$ terhadap inveksi tobacco mosaik virus (TMV) pada beberapa varietas tembakau virginia (Nicotiana tabacum L.). Jurnal HPT, 2(1): $102-$ 109.

Khalimah, S. 2011. Pengaruh pemberian $\mathrm{KNO}_{3}$ terhadap pertumbuhan tanaman iles-iles (Amorphophallus Muelleri Blume). Skripsi. Institut Pertanian Bogor, Bogor.

Korus, A. 2011. Level of vitamin C, polyphenols, and antioxidant and enzymatic activity in three varieties of kale (Brassica Oleracea L. Var. Acephala) at different stages of maturity. International Journal of Food Properties, 14(5): 1069 - 1080.

Koheri, A., Mariati, dan T. Simanungkalit. 2015. Tanggap pertumbuhan dan produksi bawang merah (Allium ascalonicum L.) terhadap waktu aplikasi dan konsentrasi pupuk KNO3. Jurnal Online Agroekoteknologi, 3(1): 206 - 213.

Ligor, M., and B. Buszewski. 2012. Effect of kale cultivation conditions on biosynthesis of xanthophylls. Journal of Food Research, 1(4): 74 - 84.

Migliozzi, M., D. Thavarajah, P. Thavarajah, P. Smith. 2015. Lentil and kale: complementary nutrient rich whole food sources to combat micronutrient and calorie malnutrition. Nutrients, 7(11): 9285 9298.

Mozafar, A. 2008.Nitrogen fertilizers and the amount of vitamins in plants: A review. Journal of Plant Nutrition, 16(12): 2479 - 2506.

Purnomo, Y. 2013. Pengaruh dosis pupuk $\mathrm{KNO}_{3}$ dan petroganik terhadap pertumbuhan dan produksi tanaman mentimun (Cucumis sativus L.) Varietas Harmony. Skripsi. Universitas Islam Kediri, Kediri.

Ramadiana, S. 2011. The application of rice hull mulch and potassium nitrate on growth and yield of kailan (Brassica oleraceae var. Long Leaf). J. Trop Soil, 16(2): 145 - 150.

Salisbury, F. B., danC. W. Ross. 1995. Fisiologi Tumbuhan Jilid I, Institut Teknologi Bandung, Bandung.

Sikora, E., andI. Bodziarczyk. 2012. Composition and antioxidant activity of kale (Brassica oleracea 1. var. acephala) raw and cooked. Acta Sci. Pol., 11(3): 239 - 248. 
p-ISSN: 1410-0029; e-ISSN2549-6786

Agrin Vol. 22, No. 1, April 2018

Zuhry, E. 2010.Aplikasi $\mathrm{KNO}_{3}$ terhadap pertumbuhan dan hasil tanaman kailan (Brassica alboglabra L.). Sagu, 9(2): $7-11$. 